Resenhas

Essays 


\title{
A produção dos grupos escolares e as práticas culturais no processo de escolarização em Minas Gerais
}

\begin{abstract}
Marcia da Silva Damazio ${ }^{1}$
GOLÇALVES, Irlen Antônio. Cultura escolar: práticas e produção dos grupos escolares em Minas Gerais (1891-1918). Belo Horizonte: Autêntica/FCH-FUMEC, 2006.

O livro de Irlen Antônio Gonçalves resulta da Tese de Doutorado em Educação defendida na Universidade Federal de Minas Gerais, em 2006, sendo fruto de investigação intensa e cuidadosa no campo da História da Educação. A pesquisa empreendida por Gonçalves traz uma contribuição significativa para a historiografia da educação brasileira, e de Minas Gerais, no período que corresponde à transição do século XIX para o século XX, mais especificamente entre 1891 e 1918, momento em que se evidenciou um conjunto de esforços para a implantação do projeto republicano no campo educacional no país. Partindo das maneiras diferenciadas do fazer dos atores envolvidos no processo, o objetivo de sua investigação foi a compreensão da produção de uma cultura escolar, que se configurou na passagem da organização do modelo das escolas isoladas para o modelo dos grupos escolares. Nessa perspectiva, os sujeitos são concebidos como aqueles que se produzem e que são, ao mesmo tempo, produzidos no dia-a-dia escolar.
\end{abstract}

\footnotetext{
1 Professora do Curso de Licenciatura em Educação Física do Departamento de Educação Física da Universidade Federal do Acre. marcia-damazio@yahoo.com.br.
} 
Já no capítulo introdutório, explicita de forma clara o referencial teórico utilizado, os questionamentos e o percurso para o alcance dos seus objetivos. Os demais capítulos apresentam as informações obtidas nas fontes documentais, quando relata os "casos" que fundamentam sua argumentação de que a escola foi produzida numa dinâmica de interação entre os envolvidos no cotidiano das escolas mineiras.

A produção da instituição escolar não é compreendida apenas a partir de dispositivos externos, mas também por meio de práticas diferenciadas de apropriação desses mesmos modelos, conforme conceitos de estratégias e táticas de apropriação de Michel de Certeau (1994), ${ }^{2}$ para quem o que importa são as "operações" que os indivíduos fazem em relação aos "produtos" que lhes são oferecidos. Logo, para Gonçalves, no processo de produção de um dado modelo escolar, devem ser questionados os usos que os diretores e professores fizeram de modelos e normas que lhes foram impostos, e de que forma estes foram ressignificados na trama cotidiana. Para isso, Gonçalves se propôs a identificar também as estratégias que correspondem ao que foi prescrito em dispositivos normativos e materiais. Faz uso ainda dos conceitos de Dominique Julia e de Vinao Frago para discutir a idéia de cultura escolar, afirmando que é na tessitura do dia-a-dia que as finalidades de educação se configuram. Trabalha com o entendimento de escolarização dos saberes, a partir de Jean Herbart, e de história das disciplinas escolares fazendo referência a André Chervel. Acerca da noção de escolarização, põe em foco a reflexão de Luciano Mendes Faria Filho, que atenta para o duplo sentido de estabelecimento de processos e políticas concernentes à organização de uma rede e de mecanismos de produção de referências sociais, tendo a escola como eixo articulador de sentidos e significados.

\footnotetext{
2 CERTEAU, M. A invenção do cotidiano. Petrópolis: Vozes, 2001.
} 
O percurso empreendido na investigação se deu a partir da análise de fontes tais como mensagens presidenciais ao Congresso Mineiro, relatórios dos Secretários do Interior, leis e decretos. Os relatórios dos inspetores e diretores, cartas, ofícios e circulares indicaram as formas de produção e possibilitaram a reconstituição das práticas no interior dos grupos escolares. $\mathrm{Na}$ organização da documentação, o pesquisador agrupou numa estrutura narrativa fatos e acontecimentos em situações que denominou de "casos".

As maneiras diferenciadas de produção na escola foram problematizadas no momento da análise documental referente às reformas de instrução pública mineira proposta pelos presidentes, secretários e inspetores. A intenção do poder estatal era fundar uma outra realidade social, que passaria pela instituição escolar. Tratava-se do lugar de produção de estratégias que visavam impor "o querer e o fazer". Inúmeros dispositivos legais foram produzidos, assumindo uma feição disciplinadora, na perspectiva apontada por Michel de Foucault, o que demonstra que nos decretos que regulamentavam a instrução pública havia um teor de obrigatoriedade e controle.

Gonçalves reflete acerca da reinvenção da escola através das reformas, que evidenciaram a ausência de continuidade política para a instrução primária entre um governo e outro. A reforma de João Pinheiro da Silva de 1906 foi uma ampla tentativa de remodelação que passou pela construção de prédios e pelo estabelecimento de programas de ensino, com descrição de matérias e organização dos tempos e espaços escolares. Nesse processo, conforme relata o autor, a figura do inspetor foi ressaltada, como "a alma do ensino", ao mesmo tempo em que a tarefa de fiscalização teria sido facilitada com a implantação dos grupos escolares. São apontados, na obra, os mecanismos para controle, fiscalização e também as falas dos atores envolvidos na trama, como a reivindicação de professores, diretores e inspetores em relação à obrigatoriedade de matrícula e freqüência. 
O diálogo entre a norma e a realidade escolar a partir dos relatórios de diretores, oferece indícios de posições diferenciadas dos vários atores e produtores da escola. Mostra leituras diferenciadas dos ordenamentos normativos por parte dos sujeitos que fizeram o cotidiano escolar, ora com posturas avançadas ora com posturas impositivas, em relação à tradição legalista. Além disso, observou-se também que os relatórios dos inspetores de ensino eram mais do que uma transcrição de uma visita, eram também uma tradução de modelos de escola, tanto do modelo desenhado pelas regras e normas político-administrativas, como também do modelo do próprio inspetor de escola.

Entre os casos analisados estava a questão da organização e racionalização do tempo escolar. Havia um tempo que fora proposto pela norma e os tempos praticados pelos professores, diretores, pais, crianças. Os mecanismos de controle, antenados com as inovações tecnológicas e pedagógicas do período, tinham como função a imposição do tempo social à temporalidade do trabalho escolar. Por outro lado, as relações pedagógicas no cotidiano da escola resultaram em discussões acerca dos métodos de ensino. Gonçalves narra um caso em que os docentes mostraram-se resistentes às normas impostas em relação à aplicação de uma determinada metodologia. A escala de observação delimitada para análise traz a possibilidade de compreensão do modo como professores, diretores, inspetores e alunos, em postos hierárquicos diferentes, se apropriavam dos regimentos e programas de forma não-consensual. A fim de impor uma cultura pensada por intelectuais, políticos, diretores, inspetores - de forma a demarcar um novo modo de ser escola - aos professores já inseridos numa cultura formada internamente no seio da escola, estabeleceu-se uma dinâmica conflituosa, que fica patente em documentos como cartas, ofícios, relatórios e registros das falas dos envolvidos no processo. Havia nesse momento uma preocupação com a formação de um professor adequado ao novo modelo escolar. O próprio 
espaço escolar coletivo deveria se constituir em ambiente de estímulo, animação e aprendizagem. Os programas de ensino também eram concebidos como formativos, e concebiam até mesmo viagens à capital para visitar outros grupos escolares. São postos em relevo, então, alguns aspectos da historiografia da educação que deslocam o foco da análise para o interior das instituições escolares, lugar da produção dos saberes e práticas escolares compreendidos como "cultura escolar".

Mas a configuração dessa cultura escolar não se dá isoladamente ao espaço social mais amplo em que a escola se insere. O sistema de Instrução Pública teve na República a marca de ser mais um instrumento do Estado sobre o cotidiano da escola. Pressões sociais atuavam na conformação de um dado modelo de escola, interferindo também na produção de uma cultura escolar, através de dispositivos institucionais como manuais, regimentos, decretos. Logo, compreender a produção de um dado fenômeno cultural remete a pensar na ação dos indivíduos em diferentes instâncias, como também revelar os fatores que interagem na configuração desse processo. Entretanto, outros segmentos como alunos e comunidade (pais, grupos assistenciais, associações, Igreja) não foram em muito evidenciados na pesquisa realizada por Gonçalves. Trata-se de enfoque que merece ser contemplado no campo da historiografia da educação, como foi bem ressaltado no presente livro.

Finalmente, um dos aspectos que nos chama atenção diz respeito à forma como o autor demonstra o modo pelo qual os atores sociais engendraram as reformas escolares no dia-a-dia e, ao mesmo tempo, foram produzidas por tais reformas. As maneiras como os atores participaram das reformas fornece uma alternativa para olhar a escola de hoje, diante das imposições normativas e das limitações do cotidiano escolar atual. 
Recebimento: 13/08/2007

Aprovação: 18/10/2007

\section{Contato:}

Rua Brasilândia, 106

Rui Lino - Distrito Industrial - Rio Branco

Cep: 68900-000 - Acre - Brasil

marcia-damazio@yahoo.com.br 